\title{
Social Aspects of CCTV in France: the Case of the City Centre of Lyons
}

\author{
Emmanuel Martinais and Christophe Bétin1
}

\begin{abstract}
Inaugurated a few days after the municipal elections in spring 2001 as a result of a campaign strongly formatted by security issues, the operation of CCTV in the centre of Lyons can be seen today as part and parcel of the security-oriented policies of the new socialist local government. Through responding in part to the concerns and interests of those social groups which are more exposed to the problems posed by crime (particularly shopkeepers and residents), implementing such a policy contributes to the social construction of deviance. It not only acts to consolidate dominant social representations in the field of security, but the ways in which it is used lead to reformulation of the rules and social norms construing everyday practices and deviant behaviour in public space.
\end{abstract}

\section{Introduction}

In France, CCTV is often presented as a simple tool for the repression of criminal behaviour, which thereby guarantees life and property safety. For a town council today, the mere thought that it is confronted with a problem of crime or insecurity is enough to make recourse to surveillance cameras an obvious necessity. In a context where crime is supposedly on the increase, the ways of justifying the use of CCTV generally remain within the realm of the implicit: its social usefulness, determining factors and effects are largely neutralised by technical rationality (Rochette et Marchandet, 1998). Yet, like all technical devices, CCTV is by no means neutral. It is not beyond the bounds of social issues and power struggles. Nor is it immune to the systems of logic and the representations of the all those who work with it and the institutions that they represent. It expresses a culture, and it alters that culture.

This is what we wish to show here, basing our demonstration on the example of the city of Lyons, which inaugurated its CCTV system in the spring of 2001. The process involved in developing the technical and organisational aspects of the system, from design to implementation, were observed. Analysis effectively showed that CCTV is constructed on the basis of conflictual social relationships, that it is pervaded with prevailing social representations, and that, over and

\footnotetext{
${ }^{1}$ Laboratoire RIVES, UMR CNRS 5600, Ecole Nationale des Travaux Publics de l'Etat. Address all correspondence to the first author at ENTPE - RIVES, rue Maurice Audin, 69518 Vaulx-en-Velin cedex, France, mailto:martinais@entpe.fr
} 
above imperatives related to security, it addresses a variety of issues, notably of an economic or political nature. Firstly, then, we will examine what 'creates culture' in the field of public security in a city such as Lyons, and secondly we will study the way in which the installation of video cameras is an opportunity to reinforce pre-existing social representations. Finally, by studying the uses of CCTV and the social relationships involved in exploiting the video footage, we will see the role it plays in redefining the social norms that govern the definition of deviant practices.

\section{Insec unity and powerstruggles}

The Presqu'île (i.e. the district situated between the rivers Rhône and Saône immediately north of the confluence) is the true city centre of the urban area of Lyons (1.2 million inhabitants). It houses a variety of sectors: residential, commercial (chain stores, franchised shops, luxury shops, late-night shops, etc.), cultural (cinemas, theatres, opera house, etc.) and tourism. It also shows a high concentration of services and communications networks (underground lines, Perrache railway station), and is therefore a natural meeting place for a large number of populations, particularly for young people from the outlying towns and districts. Here as in other contexts where people and practices intermingle, insecurity feeds largely on the opposition between, on the one hand, social groups who demand 'lawful' uses of public space (shopkeepers, residents, customers, tourists), and on the other, populations whose practices and behaviour are deemed 'out of line'.

\section{The 'youth from the suburbs' as a n ic on of crime}

When they speak of insecurity, the shopkeepers and most of the residents in the area mainly refer to the presence of populations regarded as undesirable - 'dropouts' and especially 'youths from the suburbs' - on their territory, i.e. in a space which is governed by a great number of rules and social norms they themselves have implicitly accepted and/or defined. The great majority of the examples we give refer systematically to these two populations and to practices and types of behaviour which do not, formally speaking, involve acts of delinquency or crime. During a public meeting, a representative of a community association, for instance, expressed her exasperation at seeing "youths from the suburbs urinating on shop windows", "walking around with fighting dogs", or "driving past with the radio on full blast".

As a central point and one of (inevitable) social mixing, the Presqu'île is the scene of permanent social conflicts setting those who claim control of the space and its uses (the shopkeepers and some of the residents) against those who, by their practices or behaviour, are liable to disrupt or challenge pre-established order. What is basically at stake here is the appropriation of the space in question, and, for certain people, an obvious economic interest. The shopkeepers, in particular, see the presence of 'youths from the suburbs' and 'dropouts' in their environment as a (negative) influence on their custom, and consequently on their sales.

In this system of representations, which tends to distinguish between lawful and unlawful modes of occupying space, certain individuals and social groups are made into de facto threats. Since insecurity is built upon conflictual social relations, power struggles and economic interests, the image of the average delinquent ultimately matches - give or take a few details - that of the 
'youth from he suburbs'. If the shopkeepers and representatives of community associations in the Presqu' île are to be believed, the typical delinquent, the one to be feared, the one they must protect themselves from, is, therefore, fairly young, generally from so-called 'sensitive' districts, and generally of North African origin.

\section{A widespread social representation: 'imported delinquency'}

Basically, this representation of the typical delinquent merely expresses the desire of a few people to reinforce their dominance over a space that is supposed to belong to everybody. Yet this space has been appropriated by local stakeholders in the issue of urban security. Take, for example, the Lyons city councillors ${ }^{2}$. It is true that they are under permanent pressure from shopkeepers and a large number of community associations who demand greater repression and concrete measures to restore law and order. However, we should not take at face value the claims of the shopkeepers that crime is committed by young North African 'outsiders' from the suburbs. As police statistics show crime in the city centre is committed primarily by residents of the central districts not by outsiders ${ }^{3}$.

However, the same shopkeepers and community associations represent particularly influential social groups, that no political representative can really ignore (Bétin, 1999). This means that if the councillors tend to act as spokesmen for their cause, it is because they see this stand as an opportunity to build up their political capital. As one of them said, "Our responsibility as managers is to show that we have understood the message from the citizens to whom we are responsible and that we have been able to transmit that message efficiently".

But by thus echoing the concerns and justifiable demands of this part of the population, with whom they have a privileged relationship, the councillors help to strengthen the credibility of the view that city-centre delinquency is of essentially 'external' origin. They even speak of 'imported delinquency', thus reinforcing the convictions of those (shopkeepers and residents) who may yet be in doubt as to the origins and causes of insecurity. This continuous shuttling process, in which the view of one community is always more or less fuelled by that of the other, makes it easier to understand how the representation that connects the origin of delinquency in the Presqu' île to 'youths from the suburbs' eventually becomes an obvious fact. And when all is said and done, it would not even occur to any of them to challenge this connection.

\section{CCTV: an answerto the most influential pressure groups}

On the whole, the Lyons context proves the veracity of the suggestion made by Jean Remy and Liliane Voyé: when under attack, established models will not only want to protect themselves,

\footnotetext{
2 As there has been no debate on the security issue within the City Council, we have made no formal distinction between the right wing (which was in power until 2001) and the opposition. Moreover, the election of a left-wing mayor in March 2001 brought no fundamental changes (see, for instance, Le Monde $17^{\text {th }}$ and $18^{\text {th }}$ June 2001).

3 In 1999, for instance, crimes committed by people from the suburbs (Villeurbanne, Vénissieux, Vaulx-enVelin, etc.) represent $25 \%$ of the offences recorded in the Presqu'île. As for the rest, $61 \%$ involved residents of the city center : $40 \%$ from the $1^{\text {st }}$ and $2^{\text {nd }}$ districts, $21 \%$ from the others (Renard, 2001).
} 
but will furthermore reinforce their stabilising mechanisms, notably by pointing an accusing finger at any form of deviance and by insisting on the material respect of norms (Remy et Voyé, 1981). By pointing a finger at delinquency and attributing it to a specific type of population (North African youths from the suburbs), the shopkeepers and residents of the Presqu'île, with the support of their councillors, justify their belief that they live in a threatening situation, and their consequent behaviour. By creating a category of 'unlawful users' that refers explicitly to practices judged to be competitive and/or a source of dysfunction, they intend to establish their dominance and reassert their power to define the social norms governing the use of public space. But the desire to protect themselves, and the temptation to intensify stabilising mechanisms has led them go further than mere denunciation. For although in France security remains within the domain of the State, the legal guidelines and security planning act (LOPS, 21 January 1995) opened the domain of public security to the cities, through Local Security Contracts (CLS, 27 November 1998) and the relaxing of legal measures concerning CCTV systems.

\section{When a social representation is backed up by figures}

The elaboration of the City of Lyons Local Security Contract (CLS) was an important stage in the process of legitimising CCTV, in that it provided tangible elements that were to consolidate and give body to the social representation that saw city-centre crime primarily as 'imported delinquency', attributable to young North Africans from the 'sensitive' districts of the urban area. The Local Security Diagnosis (DLS) in particular, a prerequisite for the definition of the measures set out in the Local Security Contract (CLS), is clearly oriented by the desire to give real content to the category of 'imported delinquency'. Backed up with figures and crude statistical artifices, it shows (1) that the most dangerous sector in the urban area is effectively the city centre, with a crime rate ${ }^{4}$ three times higher than the national average, and (2) that the populations responsible for the offences recorded came primarily from 'sensitive' districts in the urban area (Bétin et al., 2003). The city-centre, the refore, is a resource for delinquents largely from the outskirts: thus the city is divided into sectors where, respectively, delinquency is 'emitted' and 'observed'. This serves to justify the contents and priorities set out in the Local Security Contract (CLS). In the face of this alarming diagnosis, CCTV instantly springs to mind as a measure that can provide a fast, visible response to the expectations of both a part of the population and the powerful associations of Presqu'île shopkeepers. To quote a former district councillor, "it was not completely reliable (but) the figures corroborated intuition, and intuition corroborated the figures".

The Presquîle CCTV scheme, adopted on April 25 2000, made provision for the installation of 47 mobile video cameras in an area between the lower slopes of the Croix Rousse and the south of the Presqu'île (cf. Map1), and for the creation of the City of Lyons Centre for Urban Surveillance (CSUL), which was specially designed to view the images transmitted by the video camera network. As the objectives set for this tool were to "anticipate, deter and deal with infringements on life and property safety in places presenting a high risk of assault or theft", the positioning of the cameras was studied in minute detail. For the system's administrators, it meant

\footnotetext{
4 A rate of $240 \%$ o(240 incidents recorded for 1000 inhabitants), whereas the average for the city of Lyons is $128,5 \%$ and the national average $80 \%$ (1997). But whereas the events recorded in the Presqu'île should logically be related to the average number of people frequenting the hypercentre (350 000 per day), they are related to the number of inhabitants of an ordinary residential district $(27800)$.
} 
implanting the 'eyes' of the surveillance centre in places where there were things to be seen, i.e. in locations that had previously been defined as being particularly 'crime-engendering', an expression that is notoriously freely interpreted by the public authorities involved (Heilmann, Vitalis, 1996).

\section{The tec hnic al rationa lisa tion of ' $c$ rime-engendering' loc ations}

Ultimately, most of the choices of camera location were determined by mapping all the places where the criminal acts recorded reached a figure deemed to be 'significant'. The crimes taken into account were: attacks on property, assault, and infractions of drugs laws, committed by day or by night. Finally, a seventh map localised all the acts mentioned above and, once a threshold had been determined above which the number of acts recorded was declared significant, this map showed the 'high-risk' places in the Presqu'île that called for the presence of a camera. As in other contexts, this deterministic, 'accountant's' approach to 'risk' (Martinais, 2001) lent the necessary amount of technical rationality to the choice of camera location. The mapping was, however, by no means insignificant to those familiar with the Presqu'île (cf.: Map 1 overleaf). A comparison - albeit cursory - of the 'high-risk' places as identified by the mapping process and the effective spatial distribution of the cameras shows that a number of these were placed on the basis of other issues. This was the case in rue Emile Zola, for example, which is famous for its exclusive shops, and which was equipped at the request of an association of shopkeepers, not because the street was especially 'crime-engendering', but on the basis that this type of trade is an important asset in improving the city's prestige at an international scale.

This confirms yet again the influence of city-centre shopkeepers on the choices made by the city council. It also confirms the diversity of issues that largely determine the nature and content of measures that supposedly combat crime and its alleged progression: conflicts over the use and appropriation of spaces that bear particular importance for the community; the defence of financial and economic interests related to trade and tourism in the Presqu'île; the preservation of symbolic values linked to the image of the city centre; and the consolidation of the political power in office. From this point of view, the right to life and property safety is once again relegated to a position of secondary importance, even if it tends to justify the action taken by public authorities (Robert, 1999).

The repressive measures taken on this occasion are not, however, without repercussions on the discriminatory processes at work. By their very existence and the uses to which they are put, they contribute to the reformulation of the social norms that enable the description and definition of deviance. 


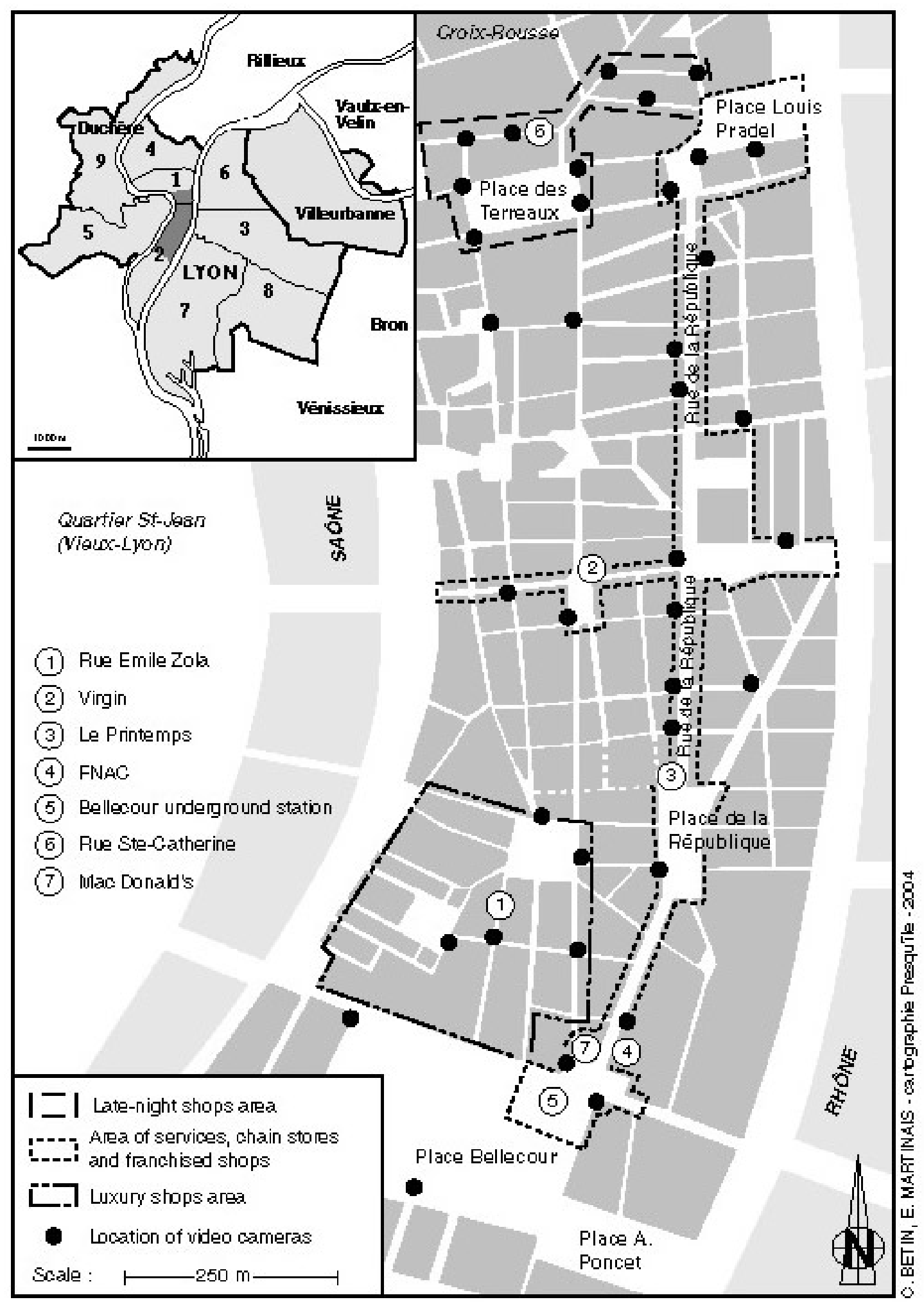

Map 1: CCTV Camera Network in the Presque'île of Lyon 


\section{When reality must bow to the collec tive representation.}

The institutional players involved in the city's management of the CCTV system are apt to restrict the debates criticising its use to the single problem of the respect of individual liberties. Some of them, such as a former councillor we met, stress "the luxury of legal guarantees for the respect of liberties" . Others brush aside the liberticidal drift of CCTV by weighing the right to individual liberty against the right to public security. Others (notably left-wingers) bring up the need to control its use by means of measures other than those provided for by law. But the creation of a 'committee on ethics' was ruled out in the early stages by the Mayor of Lyons of the time, for whom this "interest in outward appearance expressed excessive prudishness".

For the technicians whose task was to set up the CCTV network, the respect of individual liberties also implied that the ways in which the network was used should comply with the law. This is ensured by technical devices that protect the right to privacy, such as the blocking out of building windows, or the writing of codes of practice (the restriction of access to the observation room, for example). If, then, there is a risk that liberties may be infringed, it lies in the possibility of later, deliberately fraudulent use of the images obtained. The recordings could even be a further guarantee of an individual's right to his or her own image ${ }^{7}$. However, the time for which they can be retained limits this right.

According to the system's managers, CCTV is merely a technical tool, a way of using appropriate technology to exploit images. As far as they are concerned, its implementation is all the less liberticidal - and the way the images are observed all the more 'neutral' - as it is, in fact, a technical tool backed up by the authority of the law (Forest, 1999). However, when it comes to the use of new security technologies, the questions to be addressed lie beyond the futile opposition between the right to freedom and the right to security. More often than not, this basic antagonism blinds people to the issue of the real uses of security techniques, and will continue to do so as long as their social appropriation has not been examined in depth (Ocqueteau et Heilmann, 1997). As the real issues at stake are, effectively, elsewhere, let us now turn our attention to the so-called technical management of the images, that is to say more generally the way CCTV become integrated into the CSUL managers practices.

\section{Making CCTV intelligent}

In the observation room, the operators (whose task is to watch the pictures) view them 24 hours a day, on a shift basis. At the back of the room is a panel composed of four split frame monitors (their screens divided into four pictures) and four 'full screen' monitors. Each operator has a control panel with another monitor and a computer, and he can thus control a video camera to

\footnotetext{
${ }^{5}$ A reference to the minimum legal provisions in article 10 of the LOPS, specified in decree $n^{\circ} 96-926$ of 17 October 1996 and the decree on its enforcement (22 October 1996).

${ }^{6}$ Le Monde 17 May 2000.

7 The legal term can be up to one month. Should the manager refuse access, it is possible to appeal to the authoritiy for public conciliation - the local county commission - as the CNIL (the French data protection watchdog) is not legally competent in this domain (Cadoux, 1995). In Lyons, the authorities have made arrangements to the effect that, at the end of the administrative process, recordings will already have been destroyed, as they are retained for a period of eight days only.
} 
view the area whose picture he intends to 'work on'. Technically, this means that sixteen pictures can be viewed simultaneously (sixteen in 'split frame mode', four of which are 'full screen'), and this represents less than a third of the cameras in operation. Organisational constraints and the 'physical' limits often quoted by the operators lower performance figures to 12 images.

Even though technical adjustments have been planned to increase the number of 'useful' cameras if need be, an official at the CSUL reminded us that the effectiveness of the system depends more generally on its power as a deterrent ('You are being videoed'). From a preventive point of view, it entails "observing what is happening in public space, so as to detect potential incidents as early as possible". But, as the technical and human constraints involved in the operation are considerable, the managers therefore interpret the task of prevention (monitoring public spaces) in terms of optimising the technological tool. It is then a matter of id entifying high-risk behaviour ('zooming in on someone') or high-risk places (what is the best place to view?).

Potential 'high-risk' areas were defined by means of the maps originally used to determine the location of the cameras. But given the number of locations, the managers continue to ask: who should we watch, and when? To answer these questions, the Incident Analysis Centre, a municipal watchdog organisation set up within the CLS cell, is called upon to make the management of the tool more dynamic. "The Incident Analysis Centre tells us which areas of the Presqu'île (...) are particular targets at particular times", says an official at the CSUL, who can then ask the operators to view identified locations "depending on the evolution and displacement of delinquency'. This method of image management, which reduces the operators' leeway in the choice of spots to observe, is related to the statistical and mapping tools of the CLS cell and notified to the 'men in the field'. It is then possible, thanks to the technical capacities of the tool, to draw up scenarios for camera management, and to programme viewing cycles for the images (in both space and in time).

So, in collaboration with their partners at the CLS and municipal services, CSUL officials try to define a framework to prioritise the surveillance of 'high-risk' locations at the time when the greatest number of known incidents over a period of time has been recorded. This approach, which reduces the range of observation, also places specific locations under surveillance at specific times. Image management is an integral part of this project. For the managers, it is a question of 'making CCTV intelligent', of optimising its use and 'adapting it to the field'. The project requires the technological wizardry of the system, and also, prior to this, work of a social and anticipatory nature, as well as 'organising the view' of the operators. It is also based on the construction of hypotheses as to locations and periods of time, previously recorded by an in situ collation of 'acts of deviance'. Nevertheless, the fact that a specific incident occurred once or several times, at a specific point or time, does not necessarily mean that it will recur. Once the cycles have been programmed and instructions given, the task of the operators is then to use the images to spot 'high-risk' behaviour that has previously been identified as probable.

One of the basic characteristics of CCTV is to place the image at the core of the system for the prevention of acts of deviance. Like other risk management systems, insecurity prevention implies the previous use, by those involved, of data-providing instruments whose job is to evaluate and objectivize the dangers incurred in order to manage them. From this angle, it now 
seems appropriate to ask what is done with the over-abundance of images, for their suggestive power, and the fascination they exert, are no longer in doubt (Terrenoire, 1985).

\section{The determining social and economical factors involved in the objectiviza tion of images}

Depending on a 'qualitative' evaluation of the types of behaviour observed, the operators' job is to anticipate, if not police intervention, at least appropriate processing of the image to ensure that it can be used in repressive procedure. The problem then lies in the quality of the technical processing.

In this venture, whose main aim is to maximise effectiveness, especially that of the national police force $^{8}$, municipal managers have made it their objective, if not to intervene directly, at least to facilitate subsequent identification of the culprits. To do so, they work in close collaboration with the technical and scientific branches of the police force in order to adapt the operators' image recording procedure to police identification techniques. Their partnership has led to the development of a variety of scenarios for handling the 'coverage' of flagrante delicto by the two operators present: simultaneous filming of the 'situation' by cameras from different angles, "to give depth"; high-speed recording "to get close-ups" and "a facial image", because "what the police want is identification"; learning synchronisation techniques when moving from one camera to another so as not to lose the 'situation'.

The desire to improve the operators' efficiency in image production is part of a more general framework for the development of the CSUL and its role as a service provider for its 'partners'. For, unlike the CLS cell, is not answerable to the security and prevention department, but to the department of local police and urban displacements (DPDU) of the city of Lyons. Only the head of this department has police power and is empowered to sign requests to the Prefect (the local representative of the State) for the authorisation or modification of the CCTV system. However, the CSUL is an operating department that is independent of that of the local police. Over and above the 'ethical' decision not to put local policemen behind the cameras, the CSUL's independence from the police would above all make it easier, so we were told, to possibly transform the organisation's legal status and thus be able to offer a commercial service?

This partially explains the initial choice of sophisticated technology, whose "integrated upgradeability" or "means that are disproportionate to its (current) use" are vaunted by its technicians. The premises allow for future extension, and the system has been designed to be able to manage an extension of the network if and when it is connected to those of shopping malls, banks or public services (such as public transport). This 'integrated upgradeability'

\footnotetext{
8 Because "the priority is security", the managers of the CSUL distinguish between criminal offence (which falls within the competence of the national police force) and contravention of the law (e.g. illegal parking, which falls within the competence of the local police), and devote themselves primarily to the former. They do, however, point out the paradoxical aspect of a situation which amounts to placing a municipal service at the service of the national police force.

${ }^{9}$ Besides (video) surveillance of the city's property to optimise municipal public services, the councillors are also considering increasing the return on investments by creating commercial services that could offset the (appreciable) running costs of the equipment.
} 
enables the managers to envisage an automatic piloting system for the cameras, using video detection or acoustic recognition software, which would set the cameras in motion following a pre-defined 'event'. The possibility of detecting window-breaking, for example, would be an opportunity to provide shopkeepers with a service.

For the time being, the future development of the CSUL is subject to examination by the new city council, which has just equipped itself with an inter-institutional steering committee (its 'partners' at the CLS), whose role is to define the tasks and operating objectives of the CSUL, to formalise their relations by contract, and to reflect on its development. Whilst certain managers would profit directly on a professional level from the transformation of the CSUL into a service-providing organisation for new 'customers' (banks, financial backers, shopkeepers), the aim of everyone today is to ensure that the CSUL proves its ability during its experimental operating phase. The task in hand is therefore to get over the teething troubles of the procedures for the anticipation and processing of "events [flagrante delicto] which will really demonstrate effectiveness", and to go all out to encourage links with "the people who are directly involved", in order to offer them the range of services this technology can provide.

But during this so-called experimental phase, the managers of the centre have to prove its effectiveness, both to the population and to its current partners. Prevention therefore calls for moderation on both sides. To maintain or improve the 'quality of life' of the former, anticipatory action must be used soon enough to ensure that 'these things' do not happen, and this can notably be achieved due to "the growing prerogatives of the local police in terms of public peace". In concrete terms, this means: helping the latter to carry out repressive action, and 'doing' flagrante delicto better. Prevention is therefore a combination of anticipation and repression.

'Acts of deviance' are thus interpreted in terms of varying states of gravity, to be managed by a binary anticipation/repression system. To be operative, the system requires that the managers observe images of the social world, and, in the types of behaviour they see, that they detect signs of a particular individual 'switching' from one state to another, or even ind ications of a presumed 'secret intention' (Duclos, 1999). This, they say, can be seen in attitudes, body movements, or even specific clothing codes.

It is therefore up to the operators to asses a 'high-risk' situation or type of behaviour in the public space. How is this risk assessed and how is the picture managed? Generally speaking, the task of CSUL managers is to spot "any behaviour that does not abide by the rules of society", and anything which they consider to "go beyond the normal limits of life in a given space", such as "gatherings of youths", "fast cars", "unusual situations."

This is, to say the least, a very general definition of deviant behaviour in the public space. How is one to know whether a situation is 'high-risk' or not? According to the managers, the pitfall of the "purely subjective interpretation" is avoided by giving the operators a short training course in police know-how. It is as if the eye of the operator were likened to that of a community policeman, who sees and then reports, the great difference being that the latter works in situ. 
In adjusting to the methods of public security professionals, the only guarantee of objectivity given by the managers is generally their technical codes for the communication of information. But an issue remains unresolved: that of the methods used by the operators to objectivize the visual information they receive. The detection of 'high-risk' behaviour largely depends on their evaluation. It is up to the operator to choose which individuals to observe in the picture he receives. It is also up to him to evaluate the behaviour he observes as 'potentially dangerous'. But according to the managers, it is not so much a question of methods of objectivizing the image and the behaviour observed, as of getting (good) results.

Consequently, what matters is not surveying public space in order to prevent (or repress) acts of delinquency, but properly surveying the people one wishes to punish. To quote an extract from an interview:

It is true that our role is to take a close look at the spots where there is the greatest chance of an event like that. If we don't see any, it means we're really bad. So when we take a look at those spots, we stand a good chance of coming across criminal situations, and we keep our eyes out for them. So if we come across one, there's nothing necessarily unusual about it, and in fact that's what our role is. Because outside, people expect results (...). That's what the operators' instructions are all about. A lot of my work is telling them 'Right, from such and such a time to such and such a time, look at such and such a neighbourhood, to see such and such a thing and look for such and such a guy" [a CSUL manager].

\section{From anticipating delinquency to describing its so-called waming symptoms}

For the managers, deviant behaviour covers a broad range of practices, from the 'gathering of youths' that are often, so we are told, likely to get out of hand, to flagrante delicto robbery. In both cases, the police are notified: the local police in the first case, to avoid a (potential) disturbance of the peace, and the national police force in the second, in a repressive capacity. In the first case, the event is deemed likely to happen, in the second it is established. In this context, whilst the gathering of youths is not (yet) a criminal offence in France, it is becoming both an indicator of a probable disturbance of the peace and a potential source of 'antisocial' practices. And these practices are nowadays qualified locally as crimes, on the basis of the 'zero tolerance' theory adopted by the heads of the centre.

This is where the role of the image is important, in that it is not the (hitherto uncommitted) acts that are considered deviant, but the behaviour as displayed to the operator on the screen. Thus, as displayed on the screen, any gathering of youths in the public space may represent a sign of practices corresponding to a disturbance of the peace.

If one adds to that the material organisation of the work, which encourages the observation of certain places at specific times, it is disquieting to note that the areas marked out for priority surveillance in the code of practice for cyclical image management tally very closely with the places frequented by young people of mainly immigrant origin as part of their socialising practices 
(Forêt, 1990). These places are systematically quoted by all the partners at the CLS when they are asked which 'high-risk' locations in the Presqu'île call for close operator surveillance. For some, these locations are quite naturally "shopping sectors which are particularly busy on Saturday afternoons", centred around chain and department stores such as Virgin, Printemps and FNAC. For others they are "very busy" locations such as the rue de la République, but also "around the Bellecour underground station"10. The fact remains that the sectors marked out by the managers at the CSUL for compulsory surveillance are all frequented day and night by youths of immigrant, particularly North African, origin.

When we questioned these same managers in more informal circumstances on the 'effectiveness' expected from CCTV in the Presqu'ile, they acknowledged that the system is still far from able to curb all forms of crime, but that it is particularly useful and effective in the fight against the well-known phenomenon of 'imported delinquency', thus reminding us which people are really the ones on which to keep an eye.

Here again, the creation by public security stakeholders and systems in Lyons of a category for analysis (imported delinquency) is reified in the exploitation of the pictures by the creation of a category of behaviours that are presumed to be abnormal in public spaces: the gathering of youths (especially males) of immigrant origin, who are presumed to live in the suburbs. The connection between the two is based on the systematic assimilation (amongst others) of a pseudo-category of crime (antisocial behaviour) to generation groups that are qualified by their origins: ethnic (North African) and geographical (thought to be living in the suburbs)

For the national police force, the 'street crime' category covers such offences as bag - or mobile phone - snatching. To this, CLS officials have added the notion of 'antisocial behaviour', which vaguely qualifies acts which are not criminal in terms of criminal law (Mucchielli, 1999). This is no doubt the vital distinction between public 'security' and public 'peace', the new and explicit remit of the Lyons city councillor responsible for security. Once institutionalised by the players at the CLS, this pseudo category becomes a category of crime, both in the assessment of insecurity ${ }^{11}$ and in the evaluation of the CCTV system and "(its) impact on delinquency, crime, the feeling of insecurity, and antisocial behaviour in the spaces concerned"12. But in this specific case, the behaviours qualified as criminal are not defined by legal norms, but by the social norms of dominant groups who are continually asked to indicate, in no specific order, places, acts or behaviours they perceive as generating a feeling of insecurity.

\footnotetext{
10 Bellecour underground station is the interconnection of the two main lines serving the large social housing estates of the city of Lyons (la Duchère, Mermoz), and the main suburban towns, such as Vaulx-enVelin and Vénissieux, which house the poorest populations or those of immingrant origin.

11 The Incident Analysis Centre is "responsible for making as exhaustive an inventory as possible of the crimes, offences and antosocial behaviour committed in the territory to improve the understanding of insecurity phenomena".

12 In this document, issued by the City of Lyons Security and Prevention Department in July 2001, this category of deviance is used with no form of distinction or definition other than that of the crime scale of the CLS officials who established it.
} 
Going by our study, it must nonetheless be admitted that is not always clear what the dominant groups in the Presqu'île are calling into question: so-called 'antisocial' behaviour, or the mere presence in the public space of people who are presumed to behave in this way? When the CCTV managers agree that a mere "feeling of insecurity can lead to the installation of a camera in certain areas", on the basis that "it's reassuring", and because in any case "when it comes to committing a first offence CCTV has deterrent value", they do not just stigmatise behaviours that transgress the rules of propriety (antisocial behaviour). Above all, they establish a connection between people who are presumed to belong to (identity) groups and a predisposition to crime, based on the well-known (but no less questionable) maxim 'once a thief, always a thief', even if no theft has been committed. "Because as a general rule people hang around or loiter", it is easier to understand how their 'gathering of youths likely to...' indicator, which is taken into account in image management, here feeds on the belief in the existence of potentially criminal identity groups. But the very existence of these groups, and their occupation of public space, is merely a result of the stigmatising way in which they are perceived ${ }^{13}$ by the community (Authier, 1986).

\section{CCTV: a question of image fora city with an 'intemational' vocation?}

Public security managers claim that CCTV is no more than a technical tool for the management and exploitation of images. A tool which, they say, adapts itself to deviance and the evolution of deviance. For all that, this line of thinking conceals the fact that CCTV also plays a part in the construction of various forms of deviance, in the sense that the community redefines the social norms that lead deviance to be qualified as such (Becker, 1963). So it is that, because "people on the outside expect results", "experience", out of pure "common sense", ceaselessly leads to the definition of discriminatory groups and behaviours. If people continue to seek out the 'crimes' these groups commit, even if it means counting only these 'crimes' correctly, it may well be possible one day to give real content to the term 'imported delinquency', but in that case reality will have to give way to the 'scopic' view of public security managers.

The setting up of a security policy such as this is therefore not so much a question of dealing with the true causes of insecurity as of massively over-simplifying the issue of delinquency. Bearing in mind the process we have brought to light here, we cannot but subscribe to the masterly demonstration of Philippe Robert, for whom the malaise of the French suburbs is rooted in the conjunction of and increase in three processes: the social housing crisis, unemployment, and the economic integration of ethnic groups: "Regarding them as radically different from the rest makes it possible to hide the general character of these three difficulties by replacing them with a suburb-based issue. It is exactly the same for security policies: focusing on these areas alone avoids giving the issue of insecurity its deserved importance, by reducing it to scandalous pockets of danger, the proximity of which could be threatening to an otherwise healthy body" (Robert, 1999, 232).

\footnotetext{
13 A non-exhaustive example of xenophobic euphemisms seen in the documents we consulted or heard in our interviews: from "different lifestyle" and "basketball caps" to "arabs" and "gangs", which at best "take possession" of public space, at worst to use it as a "hunting ground". They are often contrasted with the "users", as if their consumer habits in the trading and functional centre of the city were not the same.
} 
In fact, public security managers have adopted a particularly simplistic conception of the city, which, quite summarily, opposes the 'keepers of the flame' to the 'new barbarians'. The result is a security policy based on a flimsy premise: delinquents are recruited in districts targeted by urban policy (the famous 'imported delinquency'), and the risk of criminal activity is high in the shopping area of the Presqu'île of Lyons, an island of wealth and prestige. The connection between the two statements is tenuous. But, as seen here, the CCTV system shows just how the players in the security stakes have nonetheless made it operational. It is a connection which has enabled the reorganisation of the city into districts, by over-dramatising conflictual socio-spatial relations that smell strongly of xenophobia: on the one hand the wealthy districts and a 'healthy' social body to be preserved as it is, on the other the poor districts against which one must simply protect oneself. A connection which, above all, makes it possible to reinforce the current tendency to build a city centre that is sanitised, impersonal and standardised, and which would be rid once and for all of those ('imported' populations) whose presence proves counterproductive to the building of a public image that meets the requirements of cities with an 'international' vocation.

\section{References}

Authier, J.-Y. (1986) Centre ville et marginalité. Les 'groupes' de jeunes de la rue de la République à Lyon. In Vant, A. (eds.) Marginalité sociale, marginalité spatiale, CNRS: 174-186.

Becker, H.-S. (1963) Outsiders. New York: The Free Press of Glencoe.

Bétin, C. (1999) Le comité Centre-Presqu'île : les épreuves du territoire. In M. Amzert (eds.) Les figures acrobatiques de l'échange inégal entre associations d'habitants et élus locaux. Le cas de la politique des espaces publics de l'agglomération lyonnaise, Paris : PUCA, 50-94.

Bétin, C., E. Martinais et M.C. Renard (2003) Sécurité, vidéosurveillance et construction de la déviance : l'exemple du centre-ville de Lyon. Déviance et Société, 27(1):3-24.

Cadoux, L. (1995) La vidéosurveillance dans les lieux publics et ouverts au public. Après-demain, 376-377: 1923.

Duclos, D. (1999) Ruée sur l'intime, la vie privée traquée par les technologies, Le Monde diplomatique, 16-17 Août.

Forest, D. (1999) La vidéosurveillance dans les lieux publics et ouverts aux publics : dispositif et application de la loi du 21 janvier 1995. Mémoire de DESS non publié, Université Paris XI, France.

Foret, C. (1990) En passant par le centre... la rue de la République à Lyon. Anthropologie d'un espace public, Marseille: Cerfise.

Heilmann, E. et A .Vitalis (1996) Nouvelles technologies, nouvelles régulations. A propos de la vidéosurveillance, Paris: CNRS/IHESI.

Martinais, E. (2001) Les sociétés locales à l'épreuve du risque urbain. Un siècle de gestion du danger dans deux contextes de l'agglomération lyonnaise (fin $X I X^{e}-$ fin $X X^{e}$ ), Thèse de doctorat non publiée, Saint-Etienne: Université Jean-Monnet, France.

Mucchielli, L. (1999) Violences urbaines, réactions collectives et représentations de classe dans la jeunesse des quartiers relégués, Actuel Marx, 26: 85-108. 
Ocqueteau, F. et E. Heilmann (1997) Droit et usages des nou velles technologies : les enjeux d'une réglementation de la vidéosurveillance. Droit et société, 36-37: 331-344.

Remy, J. et L. Voyé (1981) Ville, ordre et violence. Formes spatiales et transaction sociale. Paris: PUF.

Renard, M.-C. (2001) Les enjeux sociaux de la vidéosurveillance. Processus de mise en place d'un nouvel outil sécuritaire dans les espaces publics : l'exemple de Lyon. Mémoire de travail de fin d'études non publié, Vaulx-en-Velin: ENTPE, France.

Robert, P. (1999) Le citoyen, le crime et l'Etat. Genève-Paris : Droz.

Rochette, B. et E. Marchandet (1998) Vidéosurveillance et télésurveillance, médiations techniques et médiations politiques. In M. Ansidei, D. Dubois, D. Fleury, B. Munier (eds.) Les risques urbains. Acteurs, systèmes de prévention, Paris : Anthropos, 185-206.

Terrenoire, J.-P. (1985) Image et sciences sociales : l'objet et l'outil, Revue Française de Sociologie, 26: 509527. 